\title{
Unpublished Demotic Texts from the Ptolemaic and Roman Periods
}

\section{Sara Nabil}

\section{Department of Archaeology, Faculty of Arts, Ain Shams University, Egypt}

\section{sara.nabil@art.asu.edu.eg}

Abstract: In the present study there are 6 tax receipts and an account which they are kept in the Egyptian museum in Cairo. Some texts of them belong to the Oriental Institute's 1929/30 season of excavation at Medinet Habu, (MH 1470, MH 3338, and $\mathrm{MH} 1150)$, and the other from unknown provenance (20/10/14/1c-106, 20/10/14/1c-50, $20 / / 10 / 14 / 1 c-167$ and 20/10/14/1c-25). Both the date and the provenance of some texts could be determined from some interior evidences such as known persons.

Keywords: Demotic, ostraca, tax, account, Ptolemaic, Roman

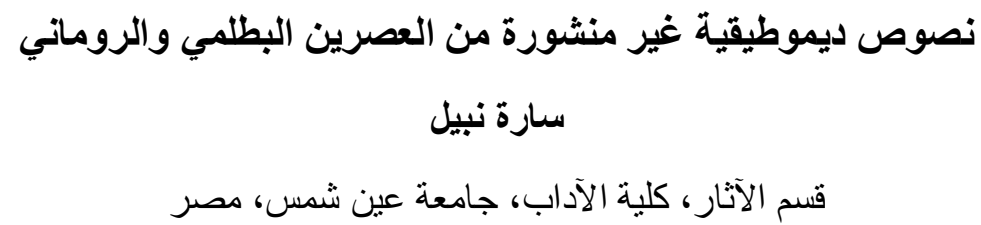

sara.nabil@art.asu.edu.eg

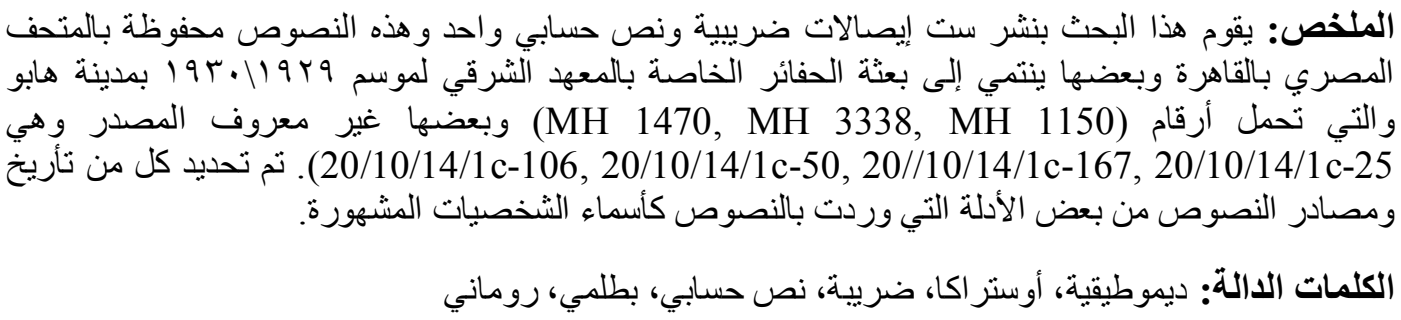

In the Ptolemaic and Roman periods texts concern tax receipts and accounts are provided us with more information about daily life in ancient Egypt. In the present study there are 6 tax receipts and an account which are kept in the Egyptian museum in Cairo. Some texts of them belong to the Oriental Institute's 1929/30 season of excavation at Medinet $\mathrm{Habu}^{1}$. (MH 1470, MH 3338, and MH 1150), and the other from unknown provenance (20/10/14/1c-106, 20/10/14/1c-50, 20//10/14/1c-167 and $20 / 10 / 14 / 1 \mathrm{c}-25)$. Both the date ${ }^{2}$ and the provenance of some texts could be determined from some interior evidences such as known persons.

This research is divided as follows:

${ }^{1}$ U. Höschler, Medinet Habu Reports vol. 2 The Architectural Survey (Chicago-Illinois: The University of Chicago Press, 1929-1930).

2 A. Depauw, A Chronological Survey of Precisely Dated Demotic and Abnormal Hieratic Sources (Köln-Leuven:Universiteit Leuven, 2007); http://aegyptologie.online-resourcen.de/Date converter for Ancient Egypt. 
- nhb-tax: Nos. 1-4.

- Unknown tax-receipt: No.5.

- Receipt of wheat: No.6.

- Grain account: No. 7.

$n h b$-tax:

The payments of the $n h b$-tax ${ }^{1}$ in the present study varied from 4 kites (no.1), 2 kites (nos.2, 4) and $1 / 4$ kite (no.3). Because the rate of this tax is not fixed, the sum of 4 kites could be considered as a full or a partial payments ${ }^{2}$. On the other, hand the rate of 2 kites and $1 / 4$ kite maybe represent installments of the tax.

It is remarkable that the word $n h b$ was written in the present texts with its usual determinatives, the striking arm, (no.2), the flesh determinative, (no.4), while it is written without a determinative in text no. 3 ,

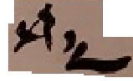
and it was broken in text no. 1 .

The provenance of the texts is Elephantine which could be determined from some internal evidences such as known scribes in nos, 1-2, 4 and using phrase $m$-s $\underline{h}$ "in writing "in no. $3^{3}$.

As for the date I follow the suggestion of both Devauchelle and Vleeming that the texts which are dated to the early Ptolemaic period and came from Elphantine, are belong to the last years of the reign of Ptolemy II Philadelphos and to the whole reign of Ptolemy III Euergetes $I^{4}$, for that reason The date of the texts is between years 245 BC. to $232 \mathrm{BC}$. of the reign of Ptolemy III Euergetes I.

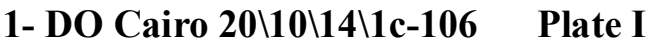

Potsherd, Yellowish.

$5.5 \times 10.5 \mathrm{~cm}$., thick. $0.7-1.1 \mathrm{~cm}$.

Date: Ptolemaic, Ptolemy III Euergetes I, 22 March 245 BC.- 20 April 245 BC.

Provenance: Elphantine (?)

\footnotetext{
${ }^{1}$ For more information about the $n h b$-tax see : S. Nabil, "Unpublished Demotic Ostraca from Medinet Habu in the Egyptian Museum" (PhD diss., Ain Shams University, 2011), 9f.

${ }^{2}$ Nabil, "Unpublished Demotic Ostraca from Medinet Habu", 10.

3 See No.3, note L. 2 in this study.

${ }^{4}$ D. Devauchelle, Ostraca Démotiques di Musée du Louvre, vol.1 (Le Caire:Institute Français d'Archéologie Orientale du Caire, 1983),13; S. P. Vleeming, Ostraka Varia, Tax Receipts and Legal Documents on Demotic, Greek, and Greek-Demotic Ostraca, Chiefly of the Early Ptolemaic Period, From Various Collections, (Leiden, New York and Köln: E. J. Brill, 1994), 6.
} 
Description: The text is incomplete as the ostracon is broken partly at the right side. The handwriting is thick, rounded and compact.

\section{Transliteration:}

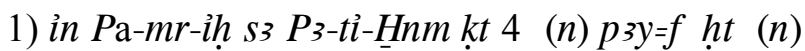

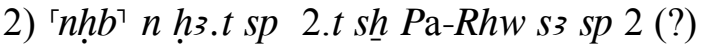

3) $\ulcorner s \underline{h}\urcorner N s-p 3-m t y$ sз $N s-p$ zy=w-t3.wy $n$ ibt 2 pr.t

4) $[s w \ldots]$

\section{Translation:}

1) $\mathrm{Pa}-m r$-ih son of $\mathrm{P}_{3}-t \hat{i}-\underline{H} \mathrm{H} m$ was paid 4 kites (of) his tax (of)

2) $\left\ulcorner h h b^{\urcorner}\right.$of year 2. Signed (by) $P a-R h w$ son of $P a-R h w(?)$

3) ${ }^{\ulcorner}$Signed by ${ }^{\urcorner} N s-p 3-m t y$ son of $N s-p 3 y=w-t 3 . w y$, in Mechir

4) $[$ day.....]

The Taxpayer $P$ a-mr-ih son of $P 3-t i-H n m$ was paid 4 kites for the $n h b$ tax in year 2 and the receipt was signed by two scribes $P \mathrm{a}-R h w$ son of $P \mathrm{a}-R h w$ (?) and Ns-p3-mty son of $N s-p 3 y=w-t 3 . w y$.

\section{Notes:}

L. 1. The Scribe $P a-R h w$ son of $P a-R h w$ (?) used the same phrase "(n) pzy=f ht $(n)$ $\left\ulcorner n h b^{\urcorner} "\right.$ "(of) his tax (of) $\left\ulcorner n h b^{\urcorner "}\right.$ in the present text and in another receipt for the same $\operatorname{tax}^{1}$.

L. 1, 3 Both the taxpayer Pa-mr-ih son of P3-ti-Hnm and the scribe Ns-p3-mty son of $N s-p 3 y=w-t 3 . w y$ seem to be unknown from previous texts especially texts concern $n h b$ tax.

L. 2. The scribe $P a-R h w^{2}$

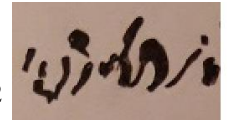

was mentioned before in two tax receipts for the same tax $n h b$. The first text published by Wångstedt ${ }^{3}$

Who read the name of this scribe as $\operatorname{Srw} 3($ ?)S3 $\operatorname{Hr}($ ?)

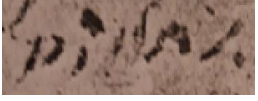
and mentioned that the text belongs to the early Ptolemaic period and came from Elphantine(?). The

${ }^{1}$ Devauchelle, O. Louvre, no. 87, L.2, 48 \& see note on L. 2 in the present text.

${ }^{2}$ E. Lüddeckens and others, Demotisches Namenbuch, vol. 6 (Wiesbaden: Dr. Ludwig Reichert Verlag, 1984), 392

${ }^{3}$ S.V. Wångstedt, Ausgewählte Demotische Ostraka (Uppsala: der Sammlung des Victoria-Museums zu Uppsala und der Staatlichen Papyrussammlung zu Berlin, 1954), no. 33 R, L.3. 
second text published by Devauchelle ${ }^{1}$ who said that this name probably read as $\mathrm{Pa}-\mathrm{r} \underline{t}$ s3 $\mathrm{Pa}-\mathrm{Hr}$ and he could not determine the provenance of the text. It is obvious that the both reading of the name are not correct and it is remarkable that

the scribe used to write the first sign of his name $P a$ as a dot while these signs represent the rest of his first name and the determinative and could not be read as $\mathrm{Hr}$.

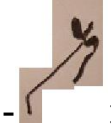

: This word sp 2 is written here with unusual long sign at the end.

L. 4.The beginning of this line is broken and it is probably contains the day which follows the date that was written at the end of the previous line.

- Year 2, Mechir= March 245 BC.- 20 April 245 BC., and belongs to the era of Ptolemy III Euergetes I.

- The provenance of the text is uncertain but it belongs probably to Elphantine as God $\mathrm{Hnm}$ is mentioned in both the personal name of the taxpayer $\mathrm{Pa}-\mathrm{mr}$-ih son of $\mathrm{P}_{3}-\mathrm{ti}$ $\underline{H} \mathrm{~nm}$ in the present text, and the personal name of the taxpayer $\mathrm{Ns}-\underline{\mathrm{H} n m}$ son of $\mathrm{Pa}-\mathrm{Mn}$ in the text published by Wångstedt ${ }^{2}$ for the same scribe.

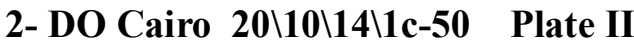

Potsherd, Brown.

$5.5 \times 8.5 \mathrm{~cm}$., thick. $0.7-1 \mathrm{~cm}$.

Date: Ptolemaic, Ptolemy III Euergetes I, 10 Jan. 242 BC.

Provenance: Elephantine

Description: The text is incomplete as the ostracon is broken partly from the left side. The handwriting is thick, compact and regular.

\section{Transliteration:}

1) in P3-šr-p3-Wsir sz P3-tỉ-Hr kt 2

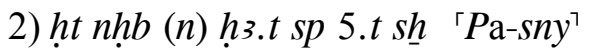

3) sз Ns- $\underline{H} n m(n)$ ḩ3.t sp 5 ibt 3 3h.t sw 20

\section{Translation:}

1) $P_{3}-\check{s} r-p 3-W \operatorname{sir}$ son of $P_{3}-t i \vec{i}-H r$ was paid 2 kites (for)

\footnotetext{
${ }^{1}$ Devauchelle, O. Louvre, no.87, L. 3, 48.

2 Wångestdt, Ausgewählte, no.33, L.1.
} 
2) (the) $n h \underline{b}$ tax (of) year 5 . Signed by ${ }^{\ulcorner} P \mathrm{a}-s n y^{\urcorner}$

3) son (of) Ns- $\underline{H} n m$ (in) year 5, Hathor, day 20

The taxpayer $P_{3}-s r-p 3-W s i r$ son of $P_{3}-t i-H r$ was paid 2 kites for the $n h b$ tax in year 5 and the receipt was signed by Pa-sny son of Ns-

\section{Notes:}

L.1. The taxpayer $P_{3}-\check{s} r-p_{3}-W \operatorname{sir}$ son of $P_{3}-t i-H r$ seems to be unknown from other texts.

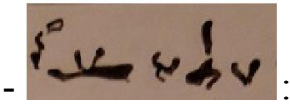

$$
\text { : The personal name } P_{3}-\check{s} r-p_{3}-W s i ̉ \text { is not familiar as } P_{3}-\check{s} r-W s i{ }^{1} \text {. }
$$

L. 2-3. The scribe $P a-s n y$ son of $N s-\underline{H} n m$ who signed also text no.4 in this study for the same tax in year 16 of Ptolemy III Euergetes I, was mentioned before in two $n h b$ tax receipts which are published by Vleeming ${ }^{2}$, and it is obvious that all texts have the same handwriting.

As for the date and the provenance of Vleeming's texts they are dated to the reign of Ptolemy III Euergetes I (years 243 BC. and 232 BC) and came from Elphantine.

L. 2 .

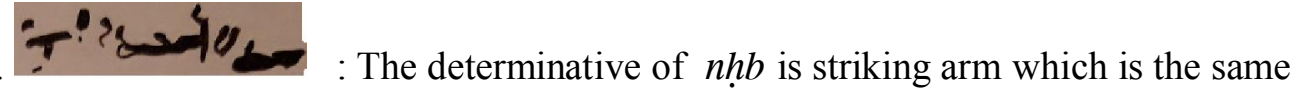
with texts were published by Vleeming ${ }^{3}$.

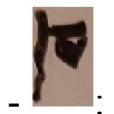

: $s \underline{h}$ sign is written as the same way with the previous texts which are signed by

the same scribe and are published by Vleeming
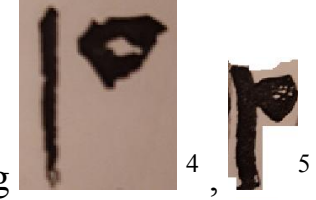
and is little different

with $s \underline{h}$ sign which is written in text no.4 for the same scribe

Year 5, Hathor, day $20=242$ BC, 10 Jan., and belongs to the reign of Ptolemy III Euergetes I.

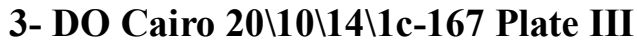

Potsherd, Brown.

\footnotetext{
${ }^{1}$ Lüddeckens and others, $N B$ vol. 4, 232.

2 Vleeming, O.Varia, nos.4-5.

3 Vleeming, O. Varia, no. 4, L.2; no. 5, L. 2.

${ }^{4}$ Vleeming, O. Varia, no.4, L.3.

5 Vleeming, O.Varia, no.5, L.3.
} 
$6.5 \times 12 \mathrm{~cm}$. , thick. $0.9-2 \mathrm{~cm}$.

Date: Ptolemaic, Ptolemy III Euergetes I, 7 Jan. 237 BC.

Provenance: Elphantine

Description: The text is complete. The handwriting is compact, neat and regular.

\section{Transliteration:}

1) in Ns-Thwwty s3 P3-wr ht kt $1 / 4$

2) nḥb (n) ḥı.t sp 9 m-sh P3-šr-p3-wr (?) sз P3-tì-Ḥr n ḥз.t sp 10

3) ibt 3 sh.t sw 18

\section{Translation:}

1) Ns-Thwty son of $P 3-w r$ was paid $1 / 4$ silver kite (for the)

2) $n h b$ (tax) (of) year 9. In (the) writing of $P_{3}-s ̌ r-p 3-w r$ (?) son of $P 3-t i ̉-H r$ of year 10 ,

3) Hathor, day 18

The taxpayer Ns-Thwty son of $P_{3-w r}$ was paid $1 / 4$ silver kite for the $n h b$ tax in year 10 for the previous year, and the receipt was signed by $P_{3}-5 r-p_{3}-w r$ (?) son of $P_{3}-t i \vec{i}-H r$.

\section{Notes:}

It seems that the taxpayer Ns-Thwty son of $P_{3}-w r$ and the scribe $P_{3-s ̌ r}-p 3-w r$ (?) son of $\mathrm{P} 3-t \hat{i}-\mathrm{Hr}$ are not known from other texts. As for the date year 10 probably belongs to the reign of Ptolemy III Euergetes I.

L. 2

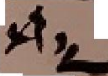

$: n h b$ is written here without any determinative.

- 1 : The phrase $m-s \underline{h}$ "in writing" always appears in texts from the early Ptolemaic period and came from Elphantine ${ }^{1}$. For that reason the provenance of the present text could be determined.

Year 10, Hathor, day $18=237$ BC, 7 Jan.

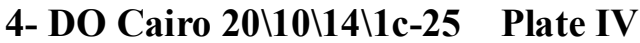

Potsherd, Gray.

$12 \times 6 \mathrm{~cm}$., thick. $0.6-0.9 \mathrm{~cm}$.

${ }^{1}$ Vleeming, O. Varia, no.2, note .b\& no.7, note.b; J.H. Johnson (ed.), The Demotic Dictionary of the Oriental Institute of the University of Chicago (Chicago-Illinois:The University of Chicago Press, 2013), S, 419. 
Date: Ptolemaic, Ptolemy III Euergetes I, 2 Dec. 232 BC.

Provenance: Elephantine

Description: The text is complete. The handwriting is small, compact and rounded.

\section{Transliteration:}

1) in Pa-nz sz P3-tì-Wsir kt 2.t $r$ ht

2) nḥb $n$ ḩ̣.t sp 16 sh Pa-sny

3) $s$ з Ns-Hnm n ḩ3.t sp 16 ibt 2 sh.t sw 14

\section{Translation :}

1) $P a-n 3$ son of $P_{3}-t i-W s i r k t$ was paid 2 kites for ( the) tax

2) (of) $n h ̣ b$ of year 16. Signed (by) Pa-sny

3) son of Ns- $\underline{H n m}$ in year 16, Paophi, day 14

The taxpayer $P$ a- $n z$ son of $P_{3}-t i-W s i r$ was paid 2 kites for the $n h b$ tax in year 16 and the receipt was signed by $\mathrm{Pa}$-sny son of Ns-Hnm who signed text no.2 in this study.

\section{Notes:}

L.1. It seems that the taxpayer $P a-n z$ son of $P 3-t i-W$ sir is unknown from other texts.

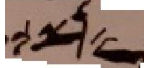

L.2-3 Year 16 seems to belong to the reign of Ptolemy III Euergetes I.

Year 16, Paophi, day $14=232$ BC. 2 Dec.

\section{Unknown Tax-Receipt:}

\section{5- M.H. 1470 Plate V}

Potsherd, Brown.

$5 \times 8.5 \mathrm{~cm}$., thick. $0.5-1.2 \mathrm{~cm}$.

Date: Ptolemaic.

Provenance: Thebes

Description: The text is incomplete as the ostracon is broken from the right and left sides. The handwriting is big and thick.

\section{Transliteration:}

${ }^{1}$ Cf. no. 2 , note L. 2 in this study. 
1) $\ulcorner$ in $\urcorner \mathrm{Pa}-\mathrm{Mn}$ s3 $\mathrm{Pa}-w n\ulcorner\ldots .\urcorner.[\mathrm{kt} \mathrm{4} 1 / 2$ ]

2) $\left.r^{r}{ }^{\urcorner} \operatorname{sttr} 2 . t 1 / 4 \quad r k t 41 / 2\right\urcorner n\ulcorner\ldots .\urcorner \quad.[\quad]$

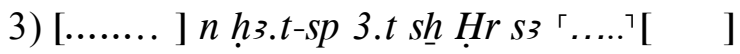

Translation:

1) $P a-M n$ son of $P a-w n\ulcorner\ldots .\urcorner \quad.\left\ulcorner\right.$ was paid $\left[4 \frac{1}{2}\right.$ kites ]

2) $\left\ulcorner\right.$ makes ${ }^{\urcorner} 2 \frac{1}{4}$ staters, makes $4 \frac{1}{2}$ kites again $\ulcorner\ldots .$.$\urcorner [ ] ]$

3) $[\ldots . . .$.$] in year 3. Signed (by) \mathrm{Hr}$ son of $\ulcorner\ldots .\urcorner.[\quad]$

The taxpayer $\mathrm{Pa}-\mathrm{Mn}$ son of $\mathrm{Pa}-w n\ulcorner\ldots .$.$\urcorner was paid 4 \frac{1}{2}$ kites for unknown tax in year 3 and the receipt was signed by $\mathrm{Hr}$ son of ${ }^{\ulcorner} . . . .{ }^{\urcorner}$

\section{Notes:}

It seems that the taxpayer $\mathrm{Pa}-\mathrm{Mn}$ son of $\mathrm{Pa}-\mathrm{wn}{ }^{\ulcorner} \ldots . .{ }^{\urcorner}$is not known from other texts.

The style of the handwriting is dated to the early Ptolemaic period.

\section{Receipt of Wheat:}

\section{6- M.H. 3338 Plate VI}

Potsherd, Brown.

$9 \times 12 \mathrm{~cm}$., thick. $0.9-1.5 \mathrm{~cm}$.

Date: Roman, Augustus, 18 Aug. 4 AD.

Provenance: Thebes

Description: The text is incomplete as the ostracon is broken partly from the right side. The handwriting is small, compact and rounded.

\section{Transliteration:}

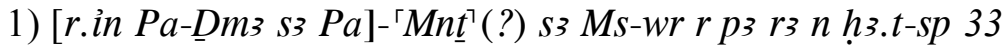

2) $\underline{h r} T 3-r m w \underline{t} 3 . t$

3) [ ] sw $1 / 4$ r sw 31/2 en n p3 hy n lypy.t

4) $[n$ wš $n \check{s} p]$ sh $n$ ḥz.t sp 33 ibt 4 šmw sw 25

\section{Translation:}

1) $[P a-D m z$ son of $P a]-\left\ulcorner M n \underline{t}^{\urcorner}(?)\right.$ son of $M s-w r$ [was paid] to the granary in year 33 
2) for $T 3-r m w \underline{t} 3 . t$

3) [ ] $1 / 4$ wheat, makes $3 \frac{1}{2}$ wheat again by the measure of the oipe,

4) [without extra charge] written in year 33, Mesore, day 25

$\mathrm{Pa}-\mathrm{Dm} 3$ son of $\mathrm{Pa}-\mathrm{Mnt}$ son of $\mathrm{Ms}$-wr delivered $3 \frac{1}{2}$ artabas of wheat to the granary on behalf of a woman called T3-rmwt3.t in year 33 of the reign of Augustus.

This kind of texts called receipts of wheat that the land tenant should deliver the remainder amount of grain to the granary after paying the rent and the harvest tax ${ }^{1}$.

\section{Notes:}

L.1. $P a-D m 3$ son of $P a-M n \underline{t}$ son of $M s-w r$ is known from many receipts are dated between year 7 to year 41 of Augustus ${ }^{2}$. He also paid a poll and bath tax for the same year of the present text ${ }^{3}$.

L.2. It seems that this line was added later, which holds the name of the woman $T 3-$ $r m w \underline{t}$ 3.t who $\mathrm{Pa}-\underline{D} m_{3}$ son of $\mathrm{Pa}-\mathrm{Mnt}$ son of $M s$-wr was paid the receipt to the granary on her behalf.

L.3. $=$ It seems that the scribe corrected the fraction from $1 / 3$ to $1 / 2$.

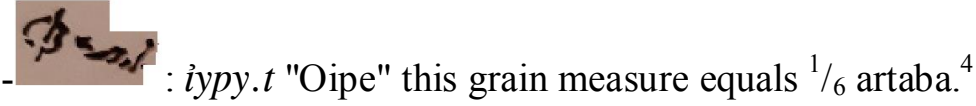

Year 33, Mesore, day $25=4$ AD. 18 Aug.

\section{Grain Account:}

\section{7- M.H. 1150 Plate VII}

Potsherd, Brown.

$8.5 \times 5.5 \mathrm{~cm}$., thick. $0.5-1 \mathrm{~cm}$.

Date: Ptolemaic

Provenance : Thebes

1 G.R. Hughes, Saite Demotic Land Leases (Chicago: The University of Chicago Press, 1952), 58; M. Lichtheim, Demotic Ostraca from Medinet Habu (Chicago-Illinois:The University of Chicago Press, 1957), 34.

${ }^{2}$ For more information about $\mathrm{Pa}-\mathrm{Dm} z$ son of $\mathrm{Pa}-\mathrm{Mnt}$ son of $M s$-wr see Nabil, "Unpublished Demotic Ostraca from Medinet Habu", 336f.

${ }^{3}$ Lichtheim, Demotic Ostraca from Medinet Habu, no.38.

4 Vleeming, “ Maße und Gewichte”, Lexikon der Ägyptologie 3 (1980),1213. 
Description: The text is incomplete as the ostracon is broken at the left side and the bottom. The handwriting is neat and regular.

\section{Transliteration:}

1) $k y[i p(?)]$

2) $\operatorname{sw} 18\ulcorner\ldots\urcorner[\quad]$

3) $\check{s}^{\complement} \quad s w \quad\ulcorner\ldots\urcorner \quad[\quad]$

4) ky ip ibt 4 [ ]

5) $s w 2 t \check{s} 16$

6) $\left.p_{3}(?)^{\ulcorner} \ldots\right\urcorner \quad[\quad]$

\section{Translation:}

1) another [ account(?) ]

2) day $18\ulcorner\ldots\urcorner[\quad]$

3) granary of wheat $\left\ulcorner\ldots{ }^{\urcorner}[\quad]\right.$

4) another account $4^{\text {th }}$ month of [ ]

5) 2 (artabas of) wheat, installment 16 [ ]

6) the (?) $\left.{ }^{\ulcorner} \ldots\right\urcorner[\quad]$

\section{Notes:}

This text represents an account of grain deals with wheat which some of it was paid in installment. From the handwriting point of view it seems that the text dated to the Ptolemaic period.

L.1. The broken part probably contains word ip "account" as the same with line 4 .

L.3.

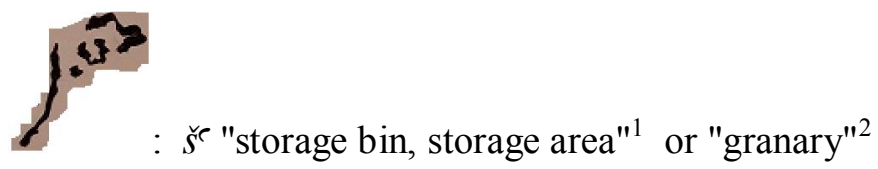

\footnotetext{
${ }^{1} \operatorname{CDD} \check{S}(10: 1), 33$.
}

${ }^{2}$ A. Erman and Hermann, Wörterbuch der ägyptischen Sprache, vol.4, Leipzig: Akademie Verlag , 1926, 409/5-7. 


\section{Plate I}

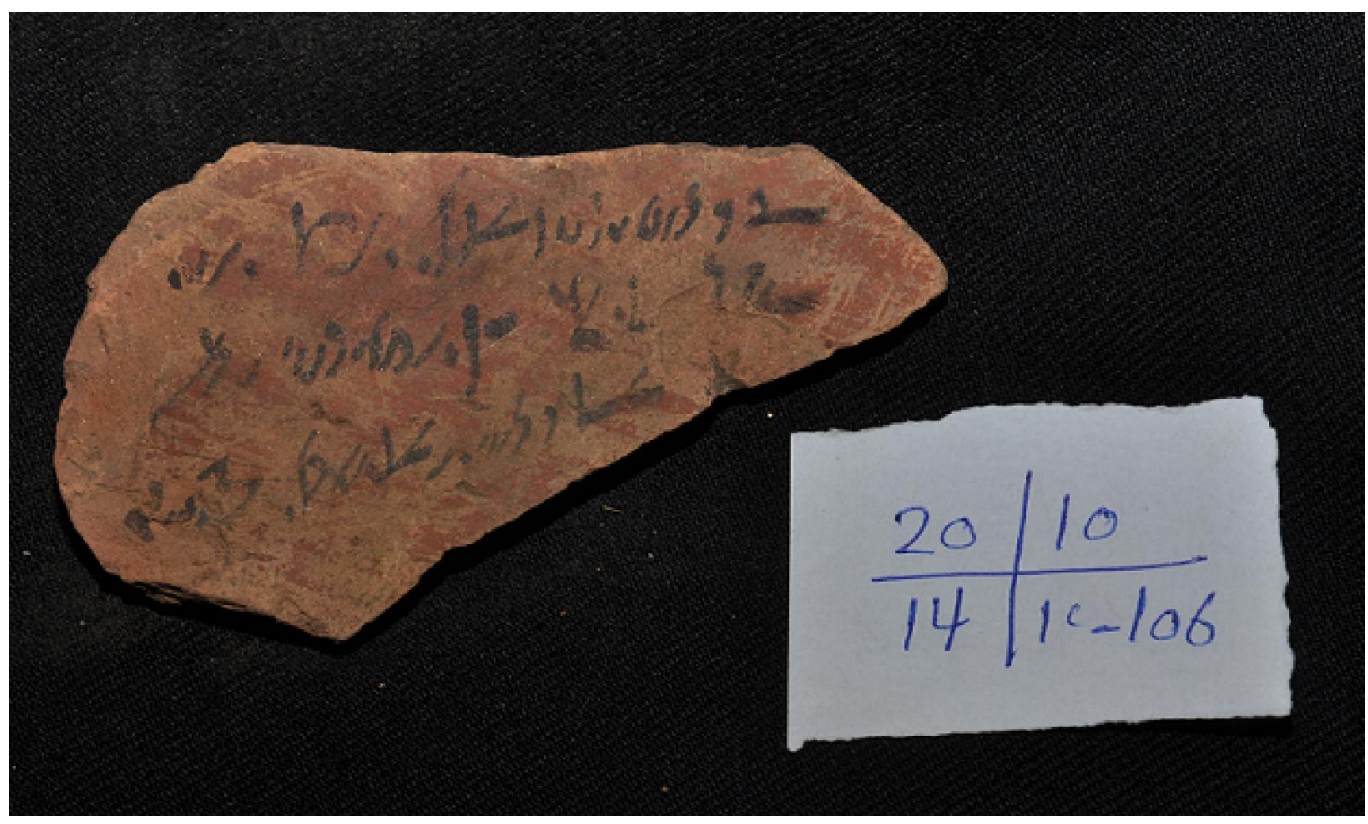

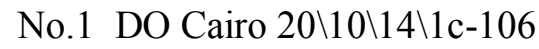

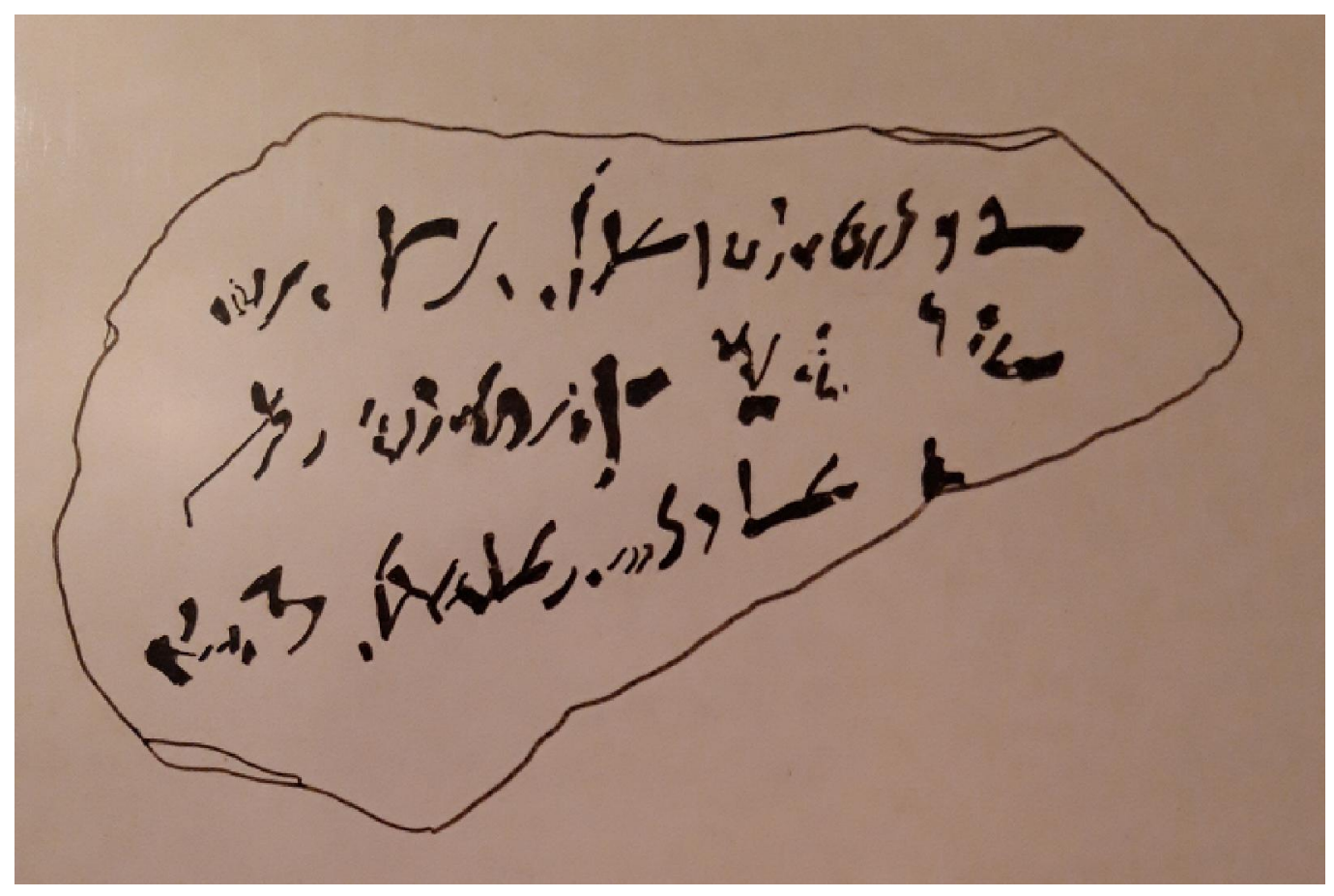

No.1 


\section{Plate II}

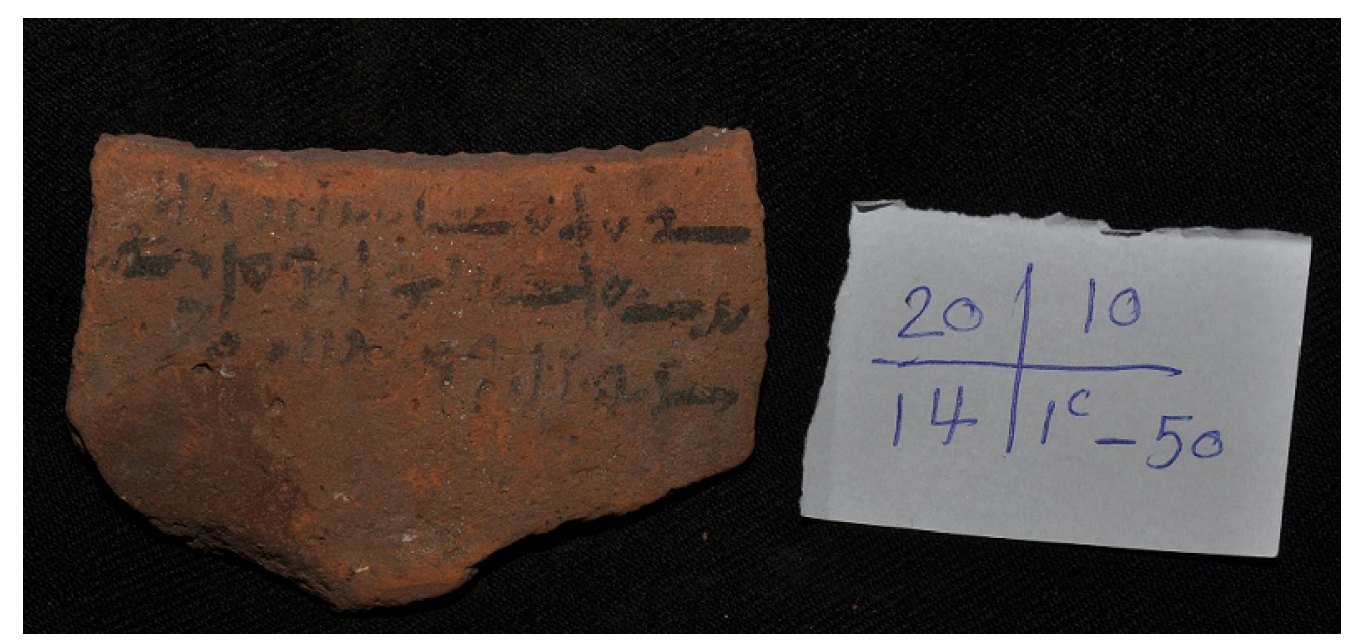

No.2 DO Cairo $20 \backslash 10 \backslash 14 \backslash 1 \mathrm{c}-50$

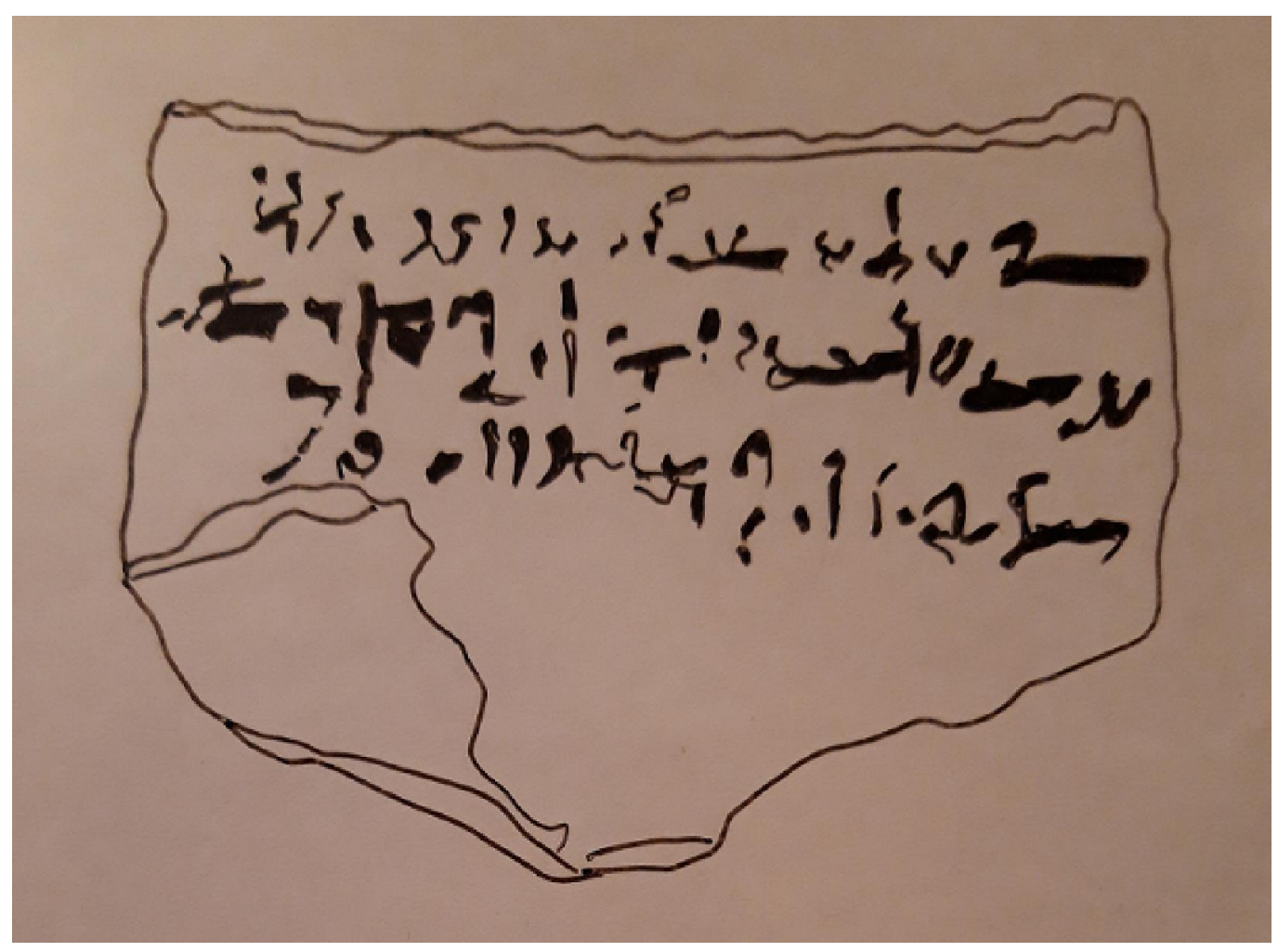

No. 2 


\section{Plate III}

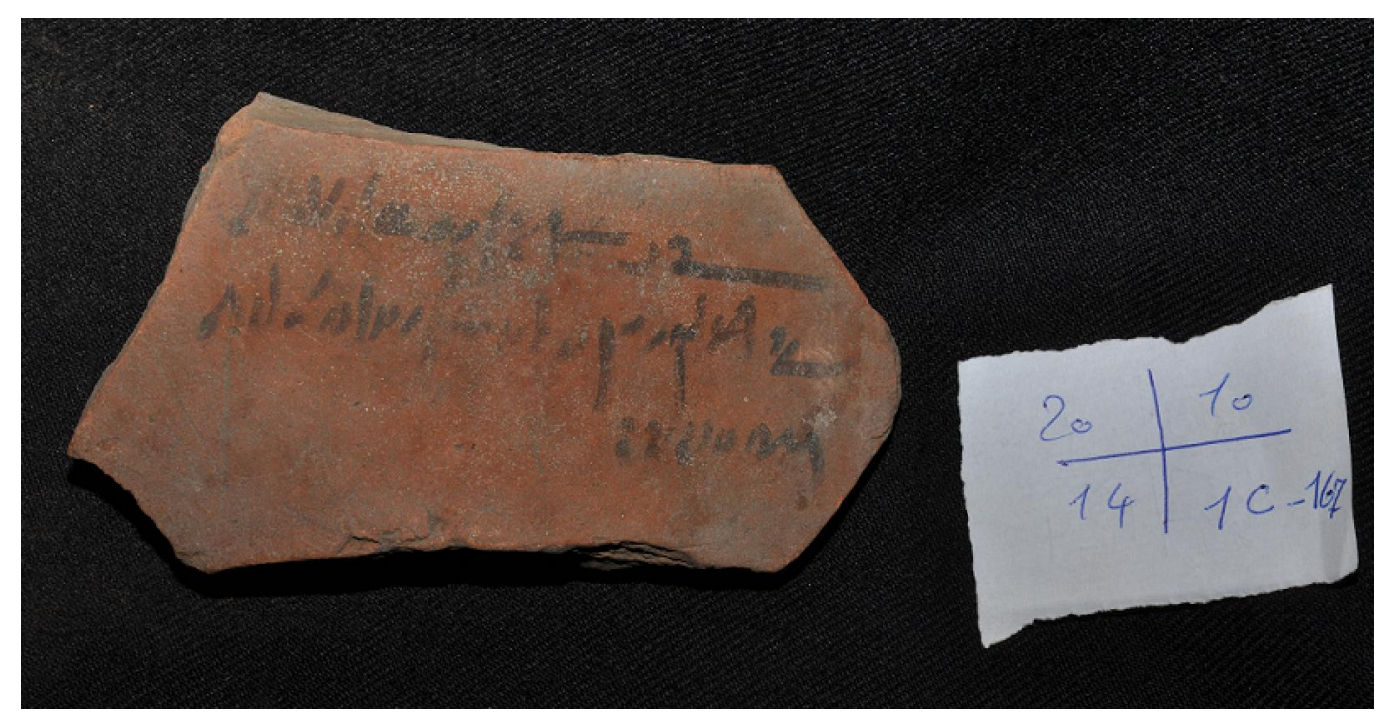

No.3 DO Cairo 20\10\14\1c-167

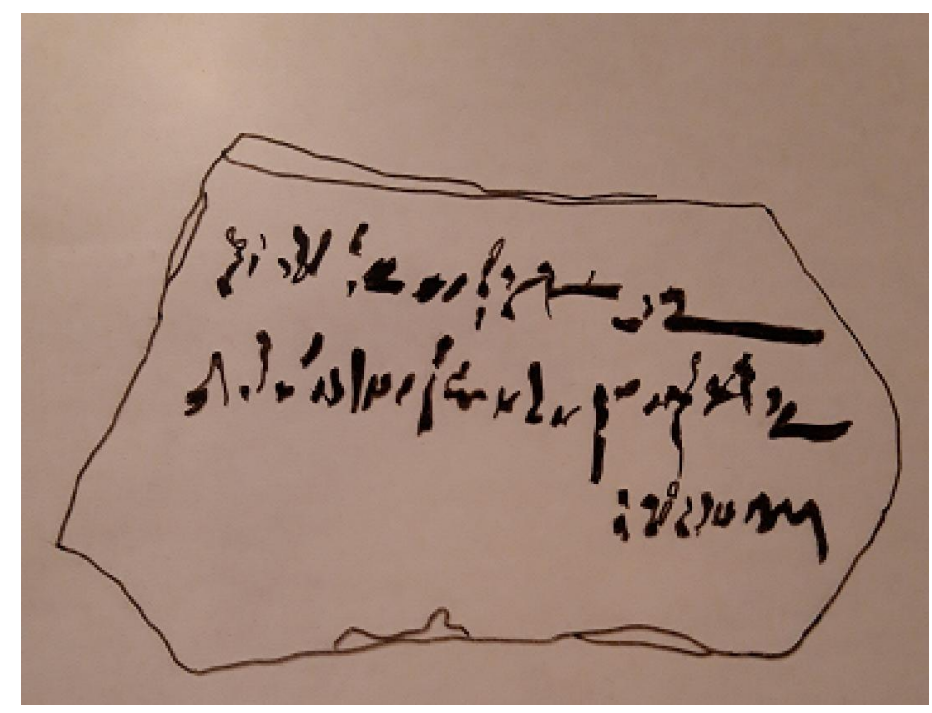

No.3 


\section{Plate IV}

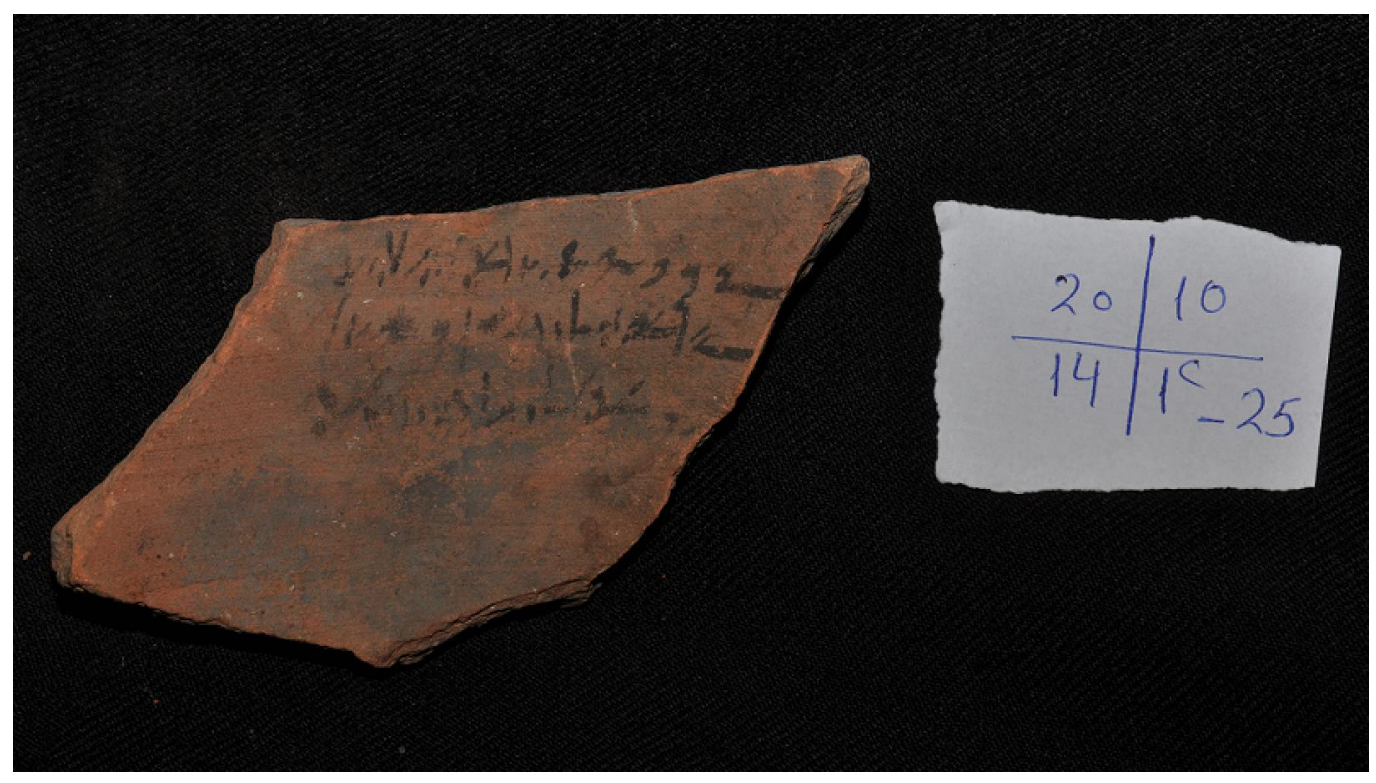

No.4 DO Cairo $20 \backslash 10 \backslash 14 \backslash 1 \mathrm{c}-25$

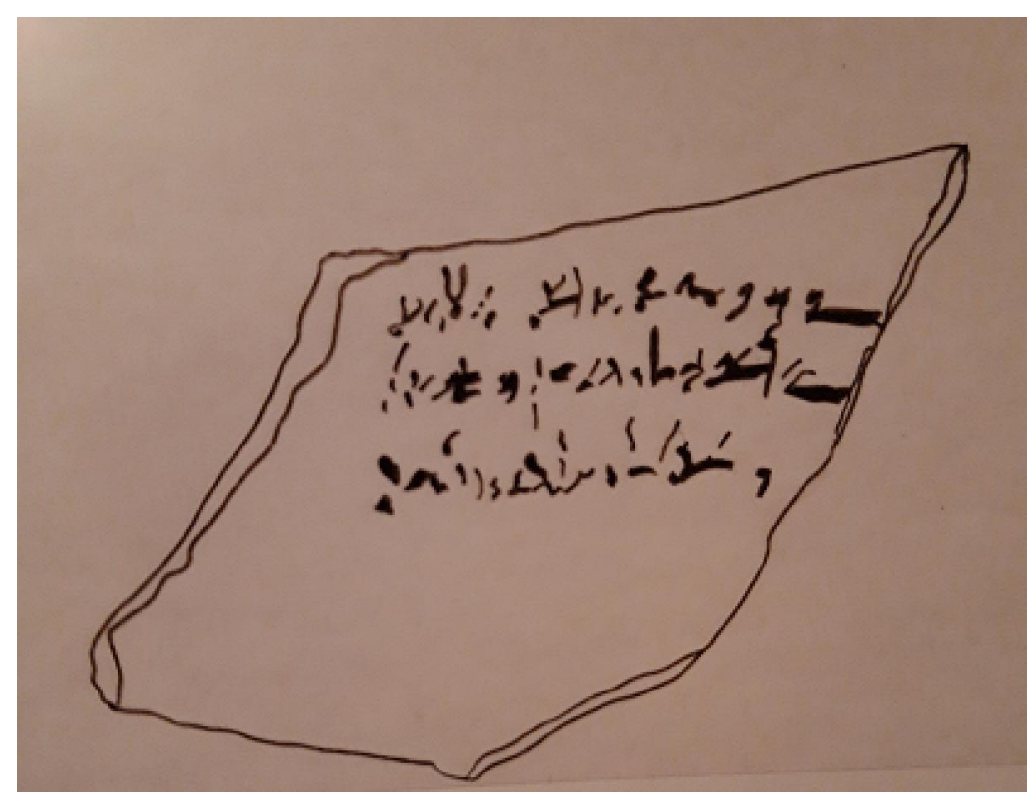

No.4 


\section{Plate V}

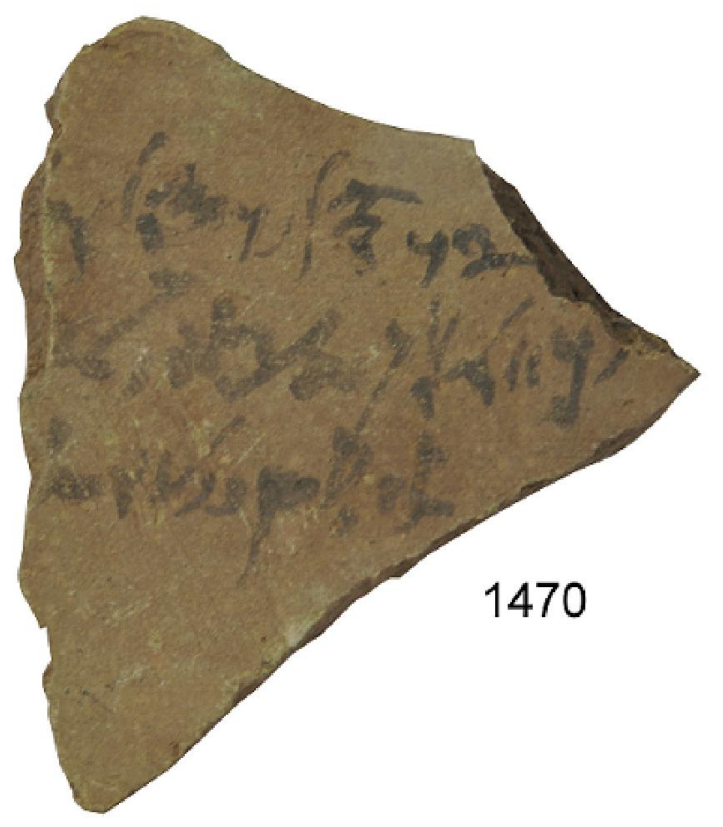

No.5 M.H. 1470

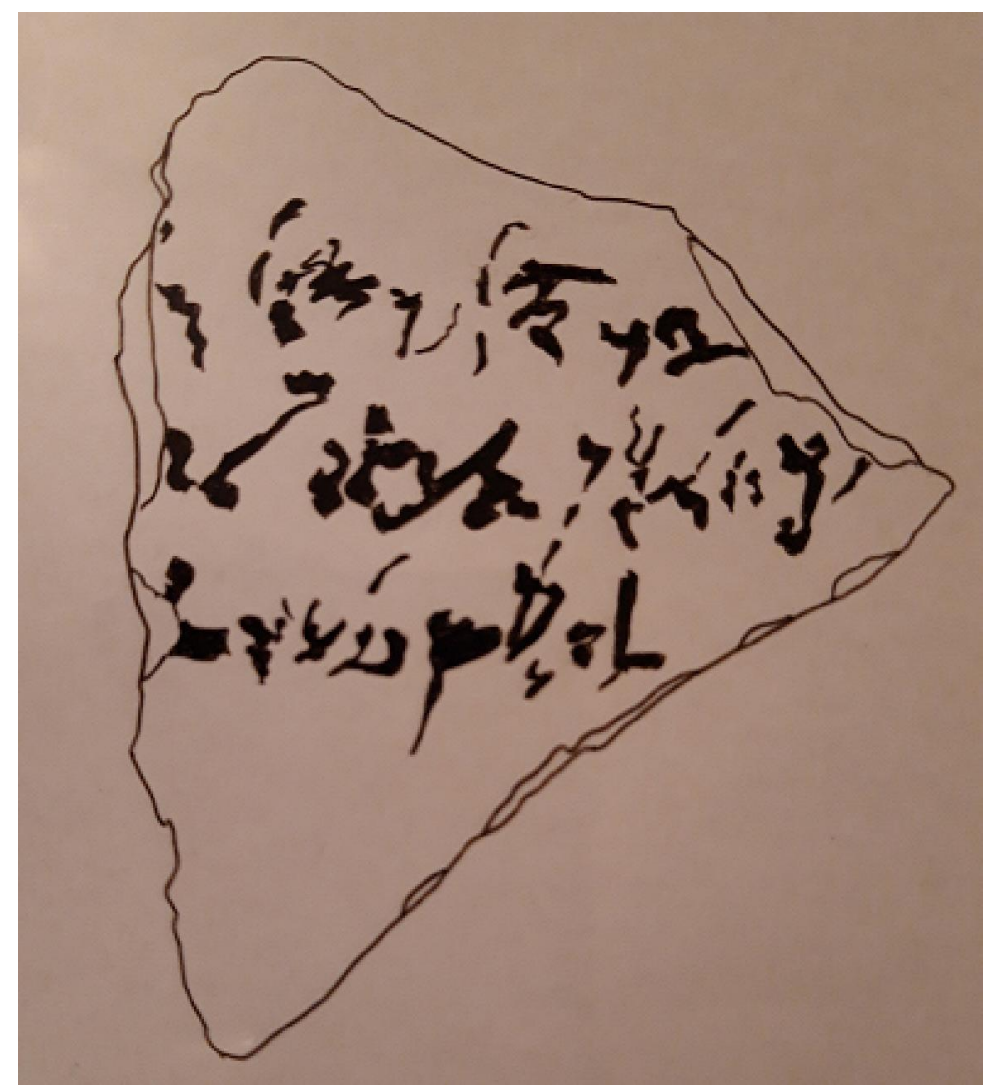

No.5 
Plate VI

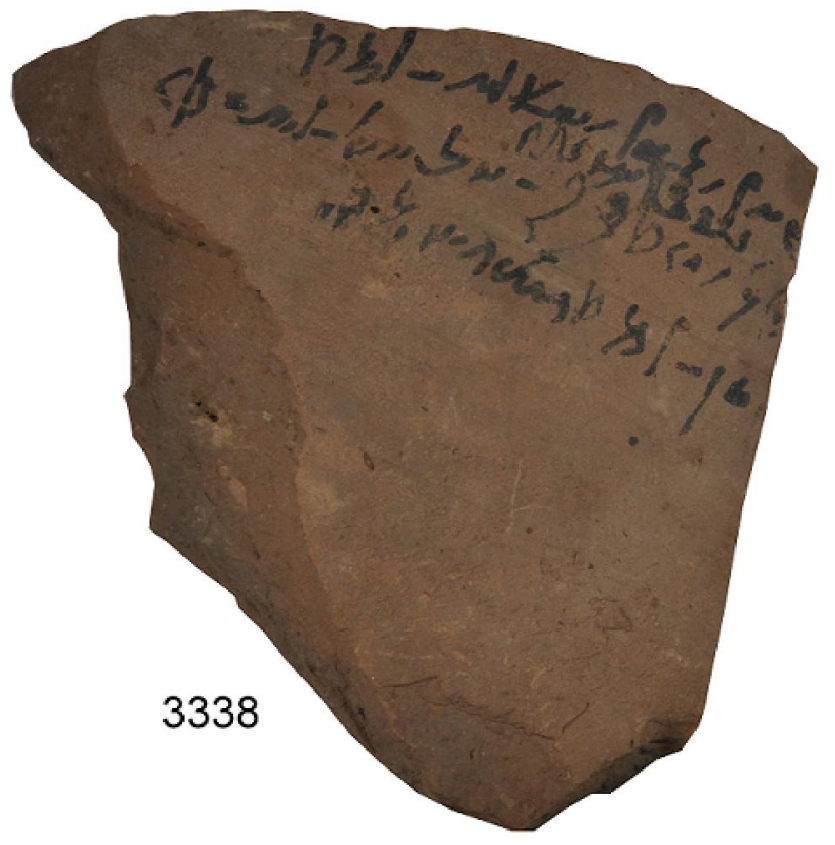

No.6 M.H. 3338

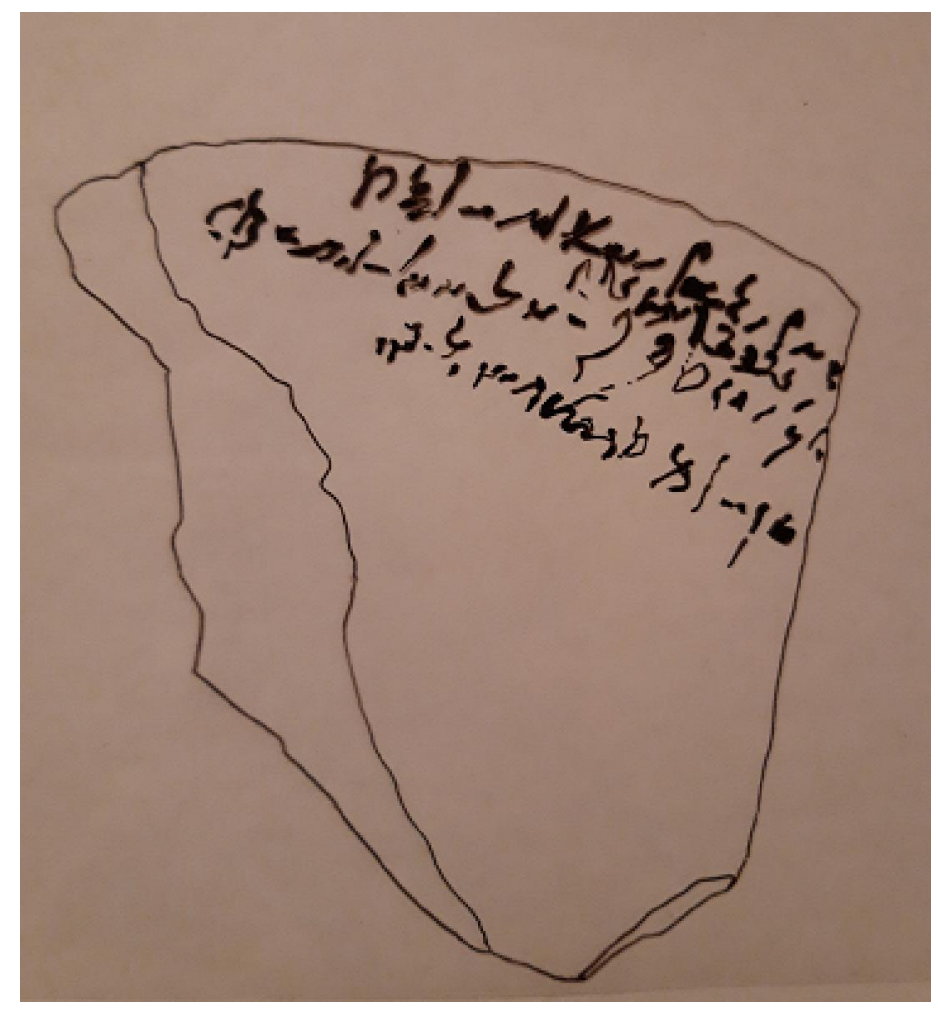

No. 6 


\section{Plate VII}

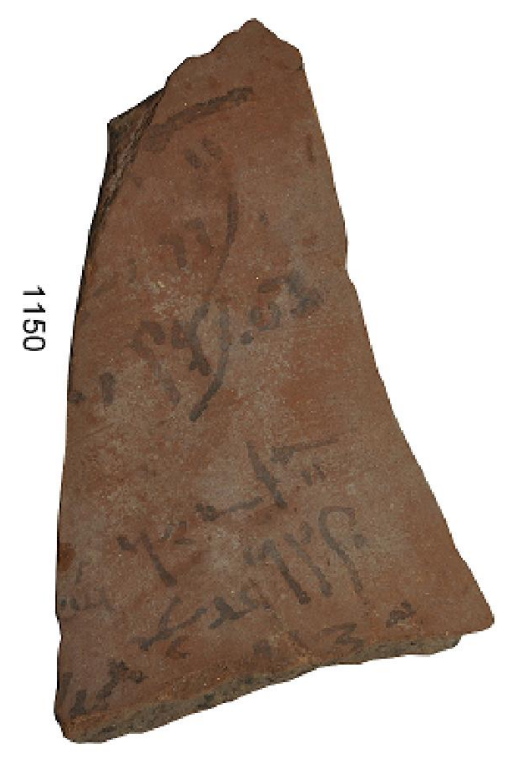

No.7 M.H. 1150

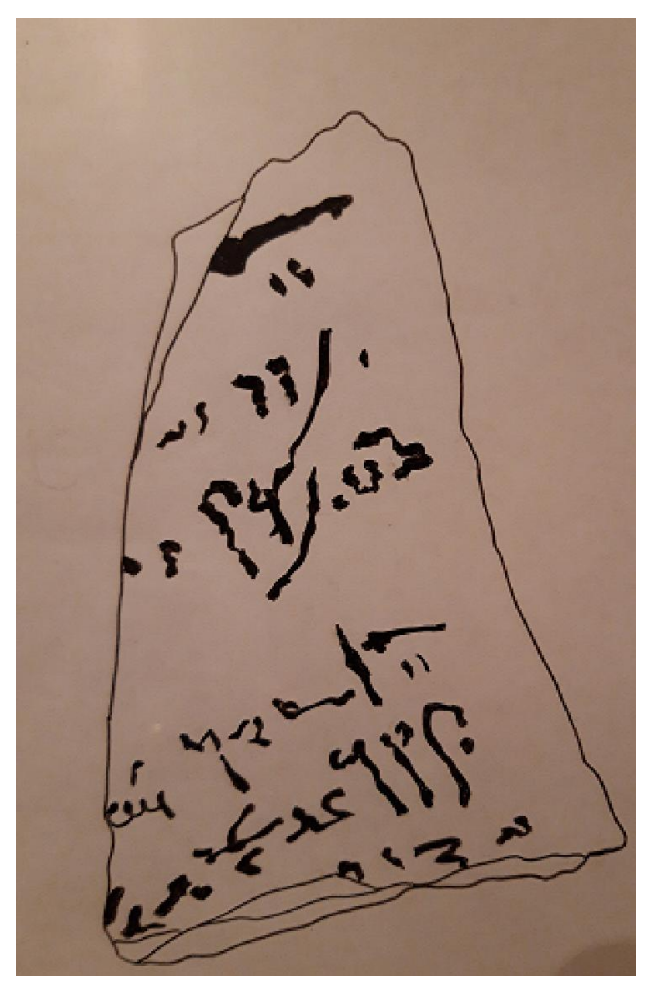

No.7 


\section{Bibliography}

\section{Dictionaries:}

- Erman, A., and Hermann, Wörterbuch der ägyptischen Sprache, vol. 4, Leipzig: Akademie Verlag, 1926.

- Johnson, J. H. (ed.), The Demotic Dictionary of the Oriental Institute of the University of Chicago, Chicago-Illinois: The University of Chicago Press, 2013.

- Lüddeckens, E. and others, Demotisches Namenbuch, vol. 6, Wiesbaden: Dr. Ludwig Reichert Verlag, 1984.

\section{References:}

- Depauw, A., A Chronological Survey of Precisely Dated Demotic and Abnormal Hieratic Sources, Köln-Leuven: Universiteit Leuven, 2007.

- Devauchelle, D., Ostraca Démotiques di Musée du Louvre, vol.1, Le Caire: Institute Français d'Archéologie Orientale du Caire, 1983

- Höschler, U., Medinet Habu Reports vol. 2 the Architectural Survey, ChicagoIllinois: The University of Chicago Press, 1929-1930.

- Hughes, G.R., Saite Demotic Land Leases, Chicago: The University of Chicago Press, 1952.

- Lichtheim, M., Demotic Ostraca from Medinet Habu, Chicago-Illinois: The University of Chicago Press, 1957.

- Vleeming, S. P., Ostraka Varia, Tax Receipts and Legal Documents on Demotic, Greek, and Greek-Demotic Ostraca, Chiefly of the Early Ptolemaic Period, From Various Collections, Leiden, New York and Köln:E. J. Brill, 1994.

- Vleeming, S. P. “ Maße und Gewichte”, Lexikon der Ägyptologie 3, (1980), 1199 1214.

- Wångstedt, S.V., Ausgewählte Demotische Ostraka,Uppsala: der Sammlung des Victoria-Museums zu Uppsala und der Staatlichen Papyrussammlung zu Berlin, 1954.

\section{Dissertations:}

- Nabil, S., "Unpublished Demotic Ostraca from Medinet Habu in the Egyptian Museum", PhD diss., Ain Shams University, 2011.

\section{Website:}

- http://aegyptologie.online-resourcen.de/Date converter for Ancient Egypt. 